\title{
Undergraduate Students of Special Education's Readiness towards the Use of Information and Technology (ICT) in Teaching and Learning the Sign Language
}

\author{
Syar Meeze Mohd Rashid', Mohd Hanafi Mohd Yasin', Noraidah Sahari @ Ashaari² \\ ${ }^{1}$ Faculty of Education, The National University of Malaysia (UKM), Bangi, Malaysia \\ ${ }^{2}$ Faculty of Information Science and Technology, The National University of Malaysia (UKM), Bangi, Malaysia \\ Email: cikgumeeze@ukm.edu.my,mhmy6365@ukm.edu.my,nsa@ukm.edu.my
}

How to cite this paper: Rashid, S. M. M., Yasin, M. H. M., \& Sahari @ Ashaari, N. (2019). Undergraduate Students of Special Education's Readiness towards the Use of Information and Technology (ICT) in Teaching and Learning the Sign Language. Creative Education, 10, 2374-2385.

https://doi.org/10.4236/ce.2019.1011169

Received: October 3, 2019

Accepted: November 4, 2019

Published: November 7, 2019

Copyright (๑) 2019 by author(s) and Scientific Research Publishing Inc. This work is licensed under the Creative Commons Attribution International License (CC BY 4.0).

http://creativecommons.org/licenses/by/4.0/

\begin{abstract}
This study intends to identify the perceptions of the undergraduate students of Special Education towards the use of information and technology (ICT) in teaching and learning the sign language. This study involved the perception of 200 undergraduate students of Special Education from 3 particular public universities. All 3 public universities offer both Special Education and the sign language course which are compulsory for the students. This study was conducted by distributing the questionnaire that consists of students' background and demography, as well as the students' readiness towards the use of information and technology (ICT) in teaching and learning the sign language. The data were then analyzed using Packages for Social Sciences (SPSS) version 20.0. The findings have gathered that majority of the students have high readiness and interest towards the use of ICT in teaching and learning the sign language with the overall mean of 4.65 and standard deviation of 0.364 . The overall mean has shown that the use of ICT is preferred by majority of the students. In conclusion, it is obvious that students are ready to use technology involved materials in the teaching and learning the sign language.
\end{abstract}

\section{Keywords}

Perspective, Sign Language, The Importance, Teaching, Learning, Undergraduate Students of Special Education, Materials, Information and Technology (ICT)

\section{Introduction}

Sign language is one of the forms of communication used by the hearing im- 
paired people. Other than that, sign language can also be used by the disable people who have trouble speaking or mute, the people who cannot learn through verbal and also the people who cannot listen well (Wilbur, 2013; Lieberman et al., 2014). Sign language is the non-verbal language or communication that does not need talking verbally. According to Maizatul Haizan Mahbob \& Noor Afzalza Nazira Ibrahim (2017), non-verbal communication is one of the ways to convey message or information to other people using signs or signals instead of using words.

The use of sign language is able to give hearing-impaired people the chance to express their feelings, opinions, and ideas. The uniqueness of sign language can be seen when the sign language provides meanings towards certain situations (Loughran, 2013). Other than that, body language and facial expression also become the attraction and intonation in the use of sign language (Wilbur, 2013). Sign language also has its own grammar and the development of sign language is developed according to the environment, habits and the practiced culture (William, 2005; Loughran, 2013).

In Malaysia, sign language is widely used as the main platform of communication to the hearing impaired people which is why the use of sign language has been used since the early level of education. In fact, sign language has also been used by the hearing impaired learners (Willoughby, 2010; Mohd et al., 2017). As the educators who teach hearing impaired learners, they need to acquire the sign language because of their years in university in order to make sure that they can convey a meaningful teaching and learning session (Mohd Huzairi et al., 2010). In conjunction to that, the sign language course has been offered in public universities that offer Special Education Course. The universities either make it a compulsory or a minor subject for students to enrol into. However, the teaching and learning of the sign language are still following the traditional method which involves only lectures and classes (Nelson et al., 2012).

According to McKee \& McKee (2012), changes are needed in the teaching and learning of the sign language by adding into the integration of ICT and technology. However, are the undergraduate students of Special Education Course ready with the use of technology and ICT in the teaching and learning of the sign language? Due to this, this study is conducted to investigate undergraduate students' perceptions and opinions towards their readiness on the use of technology and ICT in teaching and learning of the sign language.

\section{Literature Review}

Formal sign language development was identified when it started at the Federal Deaf Children's School in 1954 founded by Lady Templer (Lim, 2006). Although during that time the education system for hearing impaired (MKUP) students used the method of oralism, but students still used sign language outside of school hours (Lim, 2006). Then, in 1960 Tan Yap, who was a teacher and educational activist for MKUP, traveled to the United States to learn GKUP's sign 
language and culture there. Once back home, he spread the American sign language to the GKUP community and set up a social club and club to develop the GKUP community for 40 years until he was called as the Deaf Father in Malaysia (Lim, 2006). Subsequently, in 1978 the Malay sign-language code (KTBM) was introduced to help hearing impaired learners to improve and acquire the Malay language well (Abdullah \& Che Rabiaah, 2009). However, the KTBM is not a language but rather a hand-written code designed to facilitate the teachers in learning Malay language (Abdullah \& Che Rabiaah, 2009). This has resulted in the teachers still using a different signal structure and sentence structure from the Malay language.

In 1996, the teachers for hearing impaired learners community agreed to start the Malaysian Sign Language Development (BIM) project because it was disputed by the teachers for hearing impaired learners overseas because there was no sign language as they are still using the American Sign Language (Lim, 2006). The effort was successful until 2000, the Malaysian Sign Language Development was recognized as the official language for the teachers for hearing impaired learners in Malaysia and later recognized by the Ministry of National Unity and Community Development (Mohamed Sazali, 2004). The development of Malaysian Sign Language Development started to grown when the Malaysian Federation of Deaf (MFD) set up a Malaysian Sign Language Training Center aimed at facilitating communication between the teachers of hearing impaired learners and the typical people. Up until now, Malaysian Sign Language Development has been widely used among the teachers and even among the normal people who also want to learn about the Malaysian Sing Language (Hasuria Che, 2009).

However, the Malay sign-language code (KTBM) continues to be used in schools as a medium of communication in teaching to hearing impaired learners. This is because, the Malay sign-language code (KTBM) is not a language but a hand code used in teaching the Malay language (Abdullah \& Che Rabiaah, 2009). These codes are formulated in the structure and grammar of the Malay language to facilitate the hearing impaired learners to learn the correct language of the Malay language (Saadiah, 2009). Therefore, there are two forms of sign language that have been used in the schools of Special Education Hearing, Malaysian Sign Language (BIM) and Malay Sign-Language Code (KTBM) (Zulkifli, 2010). This is evidenced by a circular issued by the Ministry of Education Malaysia dated January 4, 2017 stating that Malaysian Sign Language (BIM) and Malay Sign-Language code (KTBM) can be used as one of the forms of communication that can be used in the education system for hearing impaired learners.

In terms of teaching and learning, sign language is used as one of the communication medium for the hearing impaired learners. One of the reasons is because it is easier to understand the lessons conveyed using sign language (Wilbur, 2013). This is also supported by McKee \& McKee (2012) who suggested that the use of sign language in teaching is not only easier to understand by the hearing impaired learners but also to attract them to learn. Similarly, in the state- 
ment by Abdullah (2014), he stated that the hearing impaired learners can quickly master something taught when it is explained using the sign language.

In addition, the use of sign language in education is to facilitate the hearing impaired learners to communicate with their teachers (Abdullah \& Che Rabiaah, 2009). The use of sign language in teaching and learning enables them to ask questions, express opinions or ideas (Ross \& Pagano, 2009). In addition, by using sign language, the hearing impaired learners are more courages to communicate and even enhances their engagement in the classroom (Ross \& Pagano, 2009). This is also supported by Abdullah Yusoff (2014) who said that communicating using sign language can train, gives confidence and increases the level of concentration for the hearing impaired learners.

It is proven that teachers who teach the hearing impaired learners must prepare themselves in mastering sign language in order for the communications between teachers and students are not interrupted (Mohd Huzairi et al., 2010). In addition, Mohd Hanafi et al. (2017) has recommended that language learning for special education teachers with hearing disabilities should be initiated and the skills should upgraded since university. This is so that when these teachers are placed in Special Education schools, they are already able to communicate better. However, sign language teaching in the higher institution that offer sign language courses only uses traditional teaching such as lectures and classes (Nelson et al., 2012). Therefore, a change in teaching to undergraduate students should be made in accordance with the current cycle of using technology (Khairah@ Asma'a et al., 2017a). This is in line with the intention of the Ministry of Education Malaysia (MOE) to ensure that the use of technology in teaching and learning at higher institution is applied and integrated (Khairah @ Asma'a et al., 2017b). In addition, this effort is seen in line with the seventh shift in 11 key changes that have transformed the country's education system in the Malaysian Education Development Plan (PPPM) (2013-2025), by utilising ICT to enhance the quality of learning in Malaysia.

Therefore, the plan developed by the MOE can benefit the undergraduate students in special education course in sign language specialization. This is because, according to Aliff \& Mohd Isa (2015), the use of ICT among students should be implemented since they are pursuing higher education. Using ICT can foster positive attitudes among students (Khairah @ Asma’a et al., 2017b). In addition, Antunes et al. (2019) said that teaching and learning sign language in higher education requires good access to ICT. This is to foster a positive environment for students to learn sign language (Antunes et al., 2019).

According to Halawani (2008), Fajardo et al. (2009) and Paudyal et al. (2019), they also said that teaching and learning sign language requires good ICT facilities to attract individuals to learn them. In addition, teaching and learning sign language using ICT can enhance students' skills and quality (Paudyal et al., 2019). A conducive environment can be formed if the sign language courses have adequate ICT facilities (Chai et al., 2017). This provides an opportunity for stu- 
dents to explore sign language more easily, systematically and systematically (Chai et al., 2017). It even gives them the satisfaction of attending sign language courses if the use of ICT is implemented in interactive courses (Aran et al., 2014).

In conclusion, recent studies have shown that sign language courses are a necessary and compulsory course for undergraduate students in special education to prepare them for teaching the hearing impaired learners. However, the sign language courses they follow need to be reformed by incorporating and integrating the use of ICT in teaching and learning.

\section{Methodology}

This study employed quantitative method using questionnaire as the instrument and the data were then analysed by using Packages for Social Sciences (SPSS) version 20.0. This study was conducted at three Institutions of Higher Education around Kuala Lumpur, Selangor and Perak which have sign language courses for undergraduate students. About 200 students from three different higher institutions responded to the questionnaire provided. The sampling was using simple random sampling technique.

The instrument was based on previous research (Pajuzi, 2018) and expert views. This instrument was modified and validated by five experts from the teaching in sign language field. They have been teaching sign language for over five years.

There are two sections that students need to fill in: part A is the demographics of the respondents and part $B$ is the students' perspective on the use of ICT in teaching and learning sign language. For section A, descriptive statistics are used to describe the respondents' demographic data in terms of frequency and percentage to provide information about respondents or students' background. Whereas for section B, five items are included in the questionnaire provided. The five scales of choice were chosen by the researcher in the questionnaire consisting of strongly disagree, disagree, somewhat agree, agree and strongly agree. The researcher has also made an analysis of the mean score based on Nunnally \& Bernstein (1994) mean score interpretation. The mean score of Nunnally \& Bernstein (1994) has four stages of proposed interpretation of the score: (Table $1)$.

\section{Findings and Discussion}

The following are the findings and discussion of this study:

Table 1. Level interpretation based on the Nunnally \& Bernstein (1994).

\begin{tabular}{ccc}
\hline Num & Mean Score & Level of Interpretation \\
\hline 1 & $1.00-2.00$ & Low \\
2 & $2.01-3.00$ & Very Low \\
3 & $3.01-4.00$ & High \\
4 & $4.01-5.00$ & Very High \\
\hline
\end{tabular}




\subsection{Findings}

Part A of the survey questionnaire was related to the demographics of the respondents involved in this study. This study involved a sample of 200 undergraduate special education students between ages 21 until 25 years old, who are studying the sign language. Within the demographic section, there is personal information that includes the gender, field, age, and age of the student. Table 2 shows the personal information obtained from 200 Bachelor of Special Education students.

Table 2 shows the information of the Bachelor students of Special Education at the three Institutions of Higher Education. In this study, the total number of respondents was 200 people comprising 48 male respondents (24\%) and 152 female respondents $(76 \%)$. The percentage of female students is higher than that of male students because the number of female students pursuing a bachelor's degree in special education is more favourable to female students than to men.

In addition, from the 200 respondents in the special education area, 94 students $(47 \%)$ took the special education stream, 18 (9\%) in the special education stream, $50(25 \%)$ in the special education stream and 38 people (19\%) who received special education without any flow or public. Respondents with a special education stream of hearing showed the most respondents in this study with a frequency of $47 \%(n=47)$ while respondents with a low visual special education flow had a frequency of $18 \%(n=18)$. This is because, there are higher institutions that offer sign language courses to all special education streams, while there are also higher institutions that offer sign language courses only to students who are taking a special education stream.

Table 2. The background information of the undergraduate students of special education.

\begin{tabular}{|c|c|c|c|}
\hline Item & Category & Frequency & Percentage (\%) \\
\hline \multirow[t]{2}{*}{ Gender } & Male & 48 & 24.0 \\
\hline & Female & 152 & 76.0 \\
\hline \multirow[t]{4}{*}{ Course } & Special Education of Hearing & 94 & 47.0 \\
\hline & Special Education of Low Vision & 18 & 9.0 \\
\hline & Special Education of Learning & 50 & 25.0 \\
\hline & General & 38 & 38.0 \\
\hline \multirow[t]{4}{*}{ Year } & Year One & 51 & 25.5 \\
\hline & Year Two & 64 & 32.0 \\
\hline & Year Three & 85 & 42.5 \\
\hline & Year Four & 0 & 0 \\
\hline \multirow[t]{4}{*}{ Age } & 25 years old and above & 12 & 6.0 \\
\hline & 23 to 24 years old & 82 & 41.0 \\
\hline & 20 to 22 years old & 106 & 53.0 \\
\hline & Below 20 years old & 0 & 0 \\
\hline
\end{tabular}


Subsequently, the respondents of this special education undergraduate student population consisted of one year students which are 51 students (25.5\%) and a total of 64 year two students (32\%). Meanwhile, the year three students are 85 students $(42.5 \%)$ and there are no respondents from year 4 students. The difference in the number of years is due to the number of students taking sign language courses at each higher institution is not the same. In addition, the absence of four-year respondents was that during this study, all year four of undergraduate special education students at each higher institution were doing their practicals in school.

On the other hand, the respondents of the Bachelor of Special Education students aged 25 and above were 12 students (6\%), 23 to 24 years were 82 students (41\%), 20 to 22 years were 106 students (53\%) and there are no respondents for students who are below 20 years old. The age difference is due to the different birth dates of the respondents and there are some students who have previously studied in Matriculation, sixth grade and preparatory centres before they continue their undergraduate studies.

Section B on the other hand explains the relation to the perspectives of special education undergraduate students on the use of ICT in teaching and learning sign language. Table 3 shows the perspective of 200 students on this subject.

The findings show that the majority of special education undergraduate students have a high degree of readiness and are interested in teaching and learning using technology. Table 3 shows the overall aspects of the readiness of undergraduate students in applying technology in teaching and learning to a high level

Table 3. Students' perspectives on the use of ICT in teaching and learning.

\begin{tabular}{|c|c|c|c|c|}
\hline Num & Item & $\mathrm{n}$ & $\begin{array}{l}\text { Mean } \\
\text { Score }\end{array}$ & $\begin{array}{l}\text { Standard } \\
\text { Deviation }\end{array}$ \\
\hline 1 & I love using ICT & 200 & 4.62 & 0.487 \\
\hline 2 & I need to learn using ICT & 200 & 4.65 & 0.480 \\
\hline 3 & I need learning sign language using ICT & 200 & 4.72 & 0.453 \\
\hline 4 & I need the use of ICT in learning sign language & 200 & 4.77 & 0.422 \\
\hline 5 & I can find references to sign language using ICT & 200 & 4.72 & 0.453 \\
\hline 6 & I can improve my sign language skills through ICT & 200 & 4.70 & 0.462 \\
\hline 7 & I focus more on learning sign language with the use of ICT & 200 & 4.54 & 0.500 \\
\hline 8 & I can revise the sign language easily with the use of ICT & 200 & 4.68 & 0.470 \\
\hline 9 & $\begin{array}{l}\text { I understand the sign language when the ICT is integrated } \\
\text { in the learning session }\end{array}$ & 200 & 4.64 & 0.481 \\
\hline 10 & I did not have any barrier towards the use of ICT in learning & 200 & 4.54 & 0.499 \\
\hline 11 & $\begin{array}{l}\text { I always try to get materials related to the sign language } \\
\text { using ICT }\end{array}$ & 200 & 4.53 & 0.500 \\
\hline 12 & $\begin{array}{l}\text { I am satisfied if the use of ICT is integrated in the teaching } \\
\text { and learning session of the sign language }\end{array}$ & 200 & 4.80 & 0.405 \\
\hline & Overall & 200 & 4.65 & 0.364 \\
\hline
\end{tabular}


of agreement with a mean score of 4.65 and a standard deviation of 0.364 . The highest mean values were shown and indicated that all students were satisfied when ICT is integrated in the teaching and learning for the sign language courses in item 12 (mean $=4.80, \mathrm{SD}=0.405, \mathrm{n}=200)$. This is because they had no obstruction when using ICT through their high level of agreement on item 10 (mean $=4.54, \mathrm{SD}=0.499, \mathrm{n}=200$ ). In addition, undergraduate students in special education always try to use online learning materials through high level of agreement on item $11(\mathrm{~min}=4.53, \mathrm{SD}=0.500, \mathrm{n}=200)$. They even need sign language learning using ICT on the third item $(\mathrm{min}=4.72, \mathrm{SD}=0.453, \mathrm{n}=200)$.

In addition, research findings indicate that undergraduate students in special education are interested in using ICT with a high score (mean $=4.62, \mathrm{SD}=$ $0.487, \mathrm{n}=200)$. In fact, these students also needed ICT in their learning $(\mathrm{min}=$ $4.65, \mathrm{SD}=0.480, \mathrm{n}=200)$. In fact, they also needed ICT (mean $=4.77, \mathrm{SD}=$ $0.422, \mathrm{n}=200$ ). In addition, ICT allows them to make references (mean $=4.72$, $\mathrm{SD}=0.453, \mathrm{n}=200$ ). Furthermore, the use of ICT enabled them to improve their sign language skills ( $m e a n=4.70, \mathrm{SD}=0.462, \mathrm{n}=200$ ). They, too, will focus more on their learning session if ICT were to be used $(\min =4.54, \mathrm{SD}=$ $0.500, \mathrm{n}=200$ ), and could easily revise the sign language studies ( $\min =4.68$, SD $=0.470, \mathrm{n}=200)$. In fact, ICT can improve their understanding of sign language (mean $=4.68, \mathrm{SD}=0.470, \mathrm{n}=200$ ). All of these factors have high mean scores on the mean score. Therefore, the findings show that the perspectives of special education undergraduate students have agreed that the use of ICT in teaching and learning should be done in the language courses offered.

\subsection{Discussion}

The findings show that 200 undergraduate students feel that learning sign language is a necessary skill and skill for them. If they are able to master the sign language, they will be able to provide understanding to the hearing impaired learners to understand the lessons presented. In fact, the mastery of a language that is easy to understand in a community will have a positive impact on communication (Maizatul Haizan \& Noor Afzaliza Nazila, 2017; Maizatul Haizan et al., 2019). One of the reasons is because sign language is a visual language that fits into the context of semiotics (theory of signs), which is the knowledge of signs and symbols (Faridah et al., 2012). Therefore, sign language can effectively convey visual imagery that shows signs or symbols in interpreting information easily. In addition, the hearing impaired learners' understanding of teaching teachers using sign language is because sign language is a non-verbal language of non-verbal communication. Although sign language does not involve speech, it is still part of the communication process that is the process of communicating information (Abdullah, 2014).

However, students also believed that ICT elements are needed to be included in the sign language courses. This is because the presence of ICT elements will make the language courses they follow to be more interesting and effective 
(Khairah @ Asma'a et al., 2017a). In fact, these ICT elements can create a positive atmosphere in the courses they follow (Khairah @ Asma'a et al., 2017b). This is also supported by Antunes et al. (2019) who said that teaching and learning sign language in higher education requires that good access to ICT for a positive atmosphere to be created among educators and students.

The findings also show that students have the desire and interest to learn sign language skills. In order to acquire these skills, students need to have a passion for learning sign language. According to Roshidah Hassan (2017), a person who learns the language should show a high degree of enthusiasm and even has an interest in learning a new language. This is because language learning not only emphasizes the meaning and matches two or more words, but it is appropriate to put the meaning in the context (Lily Haefarezan et al., 2018). However, in order to maintain the momentum of students' interest in learning sign language continuously, the use and facilities of ICT should be incorporated into the course according to the current needs and tastes of the students.

In the study of Halawani (2008), Fajardo et al., (2009) and Paudyal et al., (2019), it is shown that teaching and learning sign language requires good ICT facilities to attract the individuals to learn. The availability of ICTs in the teaching and learning of sign language can enhance students' skills and quality (Paudyal et al., 2019). A conducive environment can be formed if the sign language courses have adequate ICT facilities (Chai et al., 2017). This provides an opportunity for the students to explore sign language more easily, and more systematically (Chai et al., 2017). It even gives them the satisfaction of attending sign language courses if the use of ICT is implemented in interactive courses (Aran et al., 2014).

In conclusion, recent studies have shown that sign language courses require the application of ICT elements in teaching and learning in order to engage students in learning. In addition, the use of ICT can create a positive atmosphere in sign language courses and enable students to continue to participate more effectively.

\section{Conclusion}

Overall, the undergraduate perspective of special education on the use of ICT in teaching and learning sign language is high and positive. This is due to the reason that students feel that sign language skill is a skill they need to master. They believed that these skills can enable students to communicate better and also to teach special education students. However, the use of ICT should be incorporated into the course to make the sign language courses to be more attractive to the current tastes and technologies.

As recommendation, lecturers teaching sign language to special education undergraduate students should prepare themselves for the skills of using ICT as teaching materials to enhance the quality and interest of the students. In addition, traditional language teaching methods such as lectures need to be con- 
verted into more interactive teaching method and employ more technology materials. Furthermore, universities should strive to change the teaching and learning environment into a technological way to keep up with the current developments.

\section{Conflicts of Interest}

The authors declare no conflicts of interest regarding the publication of this paper.

\section{References}

Abdullah, Y. (2014). Memahami Komunikasi Orang Pekak. Kuala Lumpur: Dewan Bahasa dan Pustaka.

Abdullah, Y., \& Che Rabiaah, M. (2009). Memartabatkan Bahasa Orang Kurang Upaya Pendengaran. Deaf Empowerment through Sign Language Research, 1, 73-98.

Aliff, N., \& Mohd Isa, H. (2015). Tahap Penerimaan Penggunaan Telefon Bimbit Sebagai M-Pembelajaran dalam Pendidikan Islam. Journal of Islamic and Arabic Education, 5, $1-10$.

Antunes, B. R., Abreu, D. L., Rodrigrues, S. C. M., Silva, D. P., Bonini, L. M. M., \& Bissaco, M. A. S. (2019). Computerize Method for Teaching the Brazilian Sign Language. In R. Costa-Felix, J. Machado, \& A. Alvarenga (Eds.), XXVI Brazilian Congress on Biomedical Engineering. IFMBE Proceedings (Vol. 70/2, pp. 665-669). Singapore: Springer. https://doi.org/10.1007/978-981-13-2517-5_101

Aran, O., Ari, I., Akarun, L., \& Sankur, B. (2014). Sign Tutor: An Interactive System for Sign Language Tutoring. IEEE Computer Society, 16, 81-91.

https://doi.org/10.1109/MMUL.2009.17

Chai, X., Liu, Z., Li, Y., Yin, F., \& Chen, X. (2017). SignInstructor: An Effective Tool for Sign Language Vocabulary Learning. In 4th IAPR Asian Conference on Pattern Recognition (pp. 900-905). https://doi.org/10.1109/ACPR.2017.130

Fajardo, I., Vigo, M., \& Salmeron, L. (2009). Technology for Supporting Web Information Search and Learning in Sign Language. Interacting with Computers, 21, 243-256. https://doi.org/10.1016/j.intcom.2009.05.005

Faridah, I., Tika, N., Fauziah, A., Kee, C. P., \& Normah, M. (2012). Bahasa Komunikasi Visual dan Pengantaraan Produk: Satu Analisis Semiotik. GEMA Online Journal of Language Studies, 12, 257-273.

Halawani, S. M. (2008). Arabic Sign Language Translation System on Mobile Devices. International Journal of Computer Science and Network Security, 8, 251-256.

Hasuria Che, O. (2009). Penterjemahan dan Bahasa isyarat. Kuala Lumpur: Institut Terjemahan Negara Malaysia Berhad.

Khairah @ Asma'a, B., Siraj, S., \& Ghani, M. F. A. (2017a). Aplikasi Pesanan Segera Mudah Alih (Mobile Instant Messaging) Dalam Pembelajaran Kolaboratif: Satu Kajian Analisis Keperluan. Jurnal Kepimpinan Pendidikan, 4, 35-48.

Khairah @ Asma’a, B., Siraj, S., \& Ghani, M. F. A. (2017b). Penerimaan M-Pembelajaran Dalam Kalangan Pensyarah Institut Pendidikan Guru Malaysia Melalui The Unified Theory of Acceptence and Use of Technology (UTAUT): Satu Kajian Awal. Jurnal Kepimpinan Pendidikan, 4, 56-73.

Lieberman, A. M., Borovsky, A., Hatrak, M., \& Mayberry, R. I. (2014). Real-Time Processing of ASL Signs: Effects of Linguistic Experience and Proficiency (pp. 
23-26). Oakland, CA: BUCLD 38 Proceedings of University of California.

Lily Haefarezan, A., Maimun, A. L., Ashinda, A., \& Musab, S. (2018). Tahap Motivasi Holistik, Intrinsik dan Estrinsik Terhadap PembelajaranKosa Kata Bahasa Arab dalam Kalangan Graduan Universiti Awam. Asia Pacific Journal of Educators and Education, 33, 75-93. https://doi.org/10.21315/apjee2018.33.6

Lim, L. (2006). Understanding Deaf Culture Malaysian Perspectives. Kuala Lumpur: Majudiriy Foundation for the Deaf.

Loughran, S. (2013). Cultural Identity, Deafness and Sign Language: A Postcolonial Approach. LUX: A Journal of Transdisiciplinary Writing and Research Form Claremont Graduate University, 2, 1-8. https://doi.org/10.5642/lux.201301.19

Maizatul Haizan, M., \& Noor Afzaliza Nazira, I. (2017). Kecerdasan Emosi, Komunikasi Non-Verbal dan Ketrampilan Peribadi Para Pekerja dalam Konteks Komunikasi Keorganisasian. Jurnal Komunikasi: Malaysian Journal of Communication, 33, 358-382. https://doi.org/10.17576/JKMJC-2017-3301-24

Maizatul Haizan, M., Nik Anis, S. M. A., Wan Idros, W. S., \& Wan Amizan, W. M. (2019). Komunikasi Strategik dan Peranannya untuk Mewujudkan Komunikasi Berkesan dalam Organisasi. Jurnal Komunikasi: Malaysian Journal of Communication, 35, 49-67. https://doi.org/10.17576/JKMJC-2019-3502-04

McKee, R. L., \& McKee, D. (2012). Making an Online Dictionary of New Zealand Sign Language. Lexikos Journals, 23, 500-531. https://doi.org/10.5788/23-1-1227

Mohamed Sazali, S. (2004). Budaya orang kurang upaya pendengaran. Kertas persidangan keluarga kurang upaya pendengaran bahagia. Hotel Crown Princess. Kuala Lumpur. 13 Ogos.

Mohd Hanafi, M. Y., Mohd Mokhtar, T., Safani, B., \& Faten Nazren, M. (2017). The Sign Language Learning in Deaf Student and Special Education Teacher in Integration Program of Hearing Problem. Journal of ICSAR, 1, 166-174. https://doi.org/10.17977/um005v1i22017p166

Mohd Huzairi, A., Hajaratul, B. Z., Bani Hidayat, M. S., Nor Hayati, F. T., \& Nabiroh, K. (2010). Persepsi pelajar bermasalah pendengaran terhadap pembelajaran fardhu ain: Cabaran terhadap guru. In Proceedings of the 4th International Conference on Teacher Education: Join Conference UPI \& UPSI (pp. 240-250).

Nelson, L. H., White, K. R., \& Grewe, J. (2012). Evidence For Website Claims about the Benefits of Teaching Sign Language to Infants and Toddlers with Normal Hearing. Infant and Child Development, 21, 474-502. https://doi.org/10.1002/icd.1748

Nunnally, J., \& Bernstein, I. (1994). Psychometric Theory(3rd ed.). New York: McGraw-Hill.

Pajuzi, A. (2018). Pembangunan dan Penilaian m-Kandungan (m-KBAT App) Bagi Penerapan Aspek Pentaksiran Kemahiran Berfikir Aras Tinggi Dalam Sains untukGuru Pra Perkhidmatan. Unpublish Thesis, Faculty of Education, Malaysia: The National University of Malaysia (UKM).

Paudyal, P., Lee, J., Kamzin, A., Soudki, M., Banerjee, A., \& Gupta, S. K. S. (2019). Learn2Sign: Explainable Al-for Sign Language Learning. In IUI Workshop Conference (pp. 1-7). https://doi.org/10.1145/3150974

Roshidah, H. (2017). Gaya dan Strategi Pembelajaran Bahasa Melayu dalam Kalangan Pelajar Perancis. GEMA Online Journal of Language Studies, 17, 125-146. https://doi.org/10.17576/gema-2017-1701-08

Ross, A. D., \& Pagano, T. (2009). Development of Curriculum to Teach the Soft Skills Necessary for the Future Deaf and Hard of Hearing Laboratory Technician Workface. Journal of Science Education for Students with Disabilities, 1, 17-28. 
https://doi.org/10.14448/jsesd.02.0003

Saadiah, A. (2009). Pengenalan Kepada Kod Tangan Bahasa Melayu (KTBM). Selangor: Open Universiti Malaysia (OUM).

Wilbur, R. B. (2013). Changing How We Think About Sign Language, Gesture, and Agreement. Sign Language and Linguistic, 16, 221-258. https://doi.org/10.1075/sll.16.2.05wil

William, C. S. J. (2005). Sign Language Structure: an Outline of the Visual Communication Systems of the American Deaf. Journal of Deaf Studies and Deaf Education, 10, 1-37. https://doi.org/10.1093/deafed/eni001

Willoughby, L. (2010). Sign Language Users Education and Employment Levels: Keeping Pace with Changes in The General Australian Population? Journal of The Deaf Studies and Deaf Education, 16, 401-413. https://doi.org/10.1093/deafed/enq067

Zulkifli, M. A. (2010). Kesan Bahasa Isyarat Malaysia Dalam Penggunaan Kod Tangan Bahasa Melayu dalam Kalangan Pelajar Bermasalah Pendengaran. Prosiding Seminar Penyelidikan Siswazah UKM, 1, 109-121. 